\title{
Permasalahan Perkawinan Dini di Indonesia
}

\author{
Elisabeth Putri Lahitani Tampubolon \\ Fakultas Hukum Universitas Trisakti Gedung H Lantai 2 Kampus A Universitas Trisakti, Jl. \\ Kyai Tapa, Grogol, Jakarta 1440 \\ Email: Elisabetputri0904@gmail.com
}

\begin{tabular}{l} 
Artikel info \\
\hline Artikel history: \\
Diterima 03 Mei 2021 \\
Diterima dalam bentuk \\
revisi 10 Mei 2021 \\
Diterima dalam bentuk \\
revisi 17 Mei 2021 \\
\\
Keywords: \\
early marriage in indonesia; \\
causes of early marriage; impact \\
of early marriage.
\end{tabular}

\begin{abstract}
This paper aims to identify the causes and impacts of the phenomenon of early marriage in Indonesia. This paper is based on research using qualitative methods with a descriptive approach. This research has succeeded in identifying the causes and impacts of early marriage in Indonesia. Early marriages are often caused by individual factors, family and society as well as the environment in which the individual lives. In general, the factors that influence early marriage include individual factors such as free sex among adolescents, family factors such as economic needs and 2 arranged marriages, as well as environmental factors where the individual lives, such as the culture of young marriage. Some of the problems in child marriage include the factors that encourage child marriage, its effect on education, the occurrence of domestic violence, the impact on reproductive health, child birth and children's psychological health, as well as legal reviews related to child marriage.
\end{abstract}

\begin{abstract}
Abstrak
Penelitian ini bertujuan untuk mengindentifikasi penyebab dan dampak dari fenomena perkawinan dini di Indonesia. Penelitian ini didasarkan penelitian yang menggunakan metode kualitatif dengan pendekatan deskriptif. Penelitian ini berhasil mengindentifikasi penyebab dan dampak perkawinan dini di Indonesia. Pernikahan dini sering disebabkan oleh faktor individu itu sendiri, keluarga dan masyarakat serta lingkungan tempat individu tersebut tinggal. Secara umum, faktor yang mempengaruhi pernikahan dini antara lain faktor individu itu sendiri seperti seks bebas pada remaja, faktor keluarga seperti kebutuhan ekonomi dan 2 perni kahan yang telah diatur, serta faktor lingkungan tempat individu tersebut tinggal misalnya kultur nikah muda. Beberapa permasalahan dalam pernikahan anak meliputi faktor yang mendorong maraknya pernikahan anak, pengaruhnya terhadap pendidikan, terjadinya kekerasan dalam rumah tangga, dampak terhadap kesehatan reproduksi, anak yang dilahirkan dan kesehatan psikologi anak, serta tinjauan hukum terkait dengan pernikahan anak.
\end{abstract}

Kata Kunci:

perkawinan dini di indonesia; penyebab perkawinan dini; dampak perkawinan dini.
Coresponden author: Elisabeth Putri Lahitani Tampubolon Email: Elisabetputri0904@gmail.com artikel dengan akses terbuka dibawah lisensi CC BY SA 2021

\section{Pendahuluan}

Perkawinan merupakan suatu peristiwa dalam kehidupan orang yang mempengaruhi status hukum orang tersebut. KuhPerdata tidak memberikan definisi mengenai pengertiaan perkawinan. Jadi batas-batas perkawinan harus disimpulkan dari ketentuan undang-undang 
yang mengatur perkawinan. Diantara factor-faktor yang dapat mempengaruhi status hukum seseorang makan perkawinan merupakan factor yang paling berpengaruh atas kedudukan hukum orang yang terikat didalamnya. Karena perkawinan itu tercipta suatu hubungan hukum antar suami-istri, kemudian jika dalam perkawinan dilahirkan anak, maka tercipta hubungan hukum antara orang tua dengan anak, demikian pula hubungan hokum dengan keluarga masing-masing suami-istri. Terciptanya hubungan hukum tersebut membawa serta timbulnya tanggung jawab satu terhadap yang lain sebagaimana ditentukan dalam undangundang Perkawinan dini bukanlah fenomena baru, baik di Indonesia maupun di

Negara-negara lain. Menikah di usia kurang dari 18 tahun merupakan realita yang harus dihadapi sebagian anak di seluruh dunia, terutama negara berkembang. Meskipun Deklarasi Hak Asasi Manusia di tahun 1954 secara eksplisit menentang pernikahan anak, namun ironisnya, praktek pernikahan usia dini masih berlangsung di berbagai belahan dunia dan hal ini merefleksikan perlindungan hak asasi kelompok usia muda yang terabaikan. Implementasi Undang-Undangpun seringkali tidak efektif dan terpatahkan oleh adat istiadat serta tradisi yang mengatur norma sosial suatu kelompok masyarakat. Menurut United Nations Development Economic and Social Affairs (UNDESA 2010 dalam Kemkes 2015), Indonesia merupakan negara ke-37 dengan prosentase pernikahan usia muda yang tinggi dan merupakan tertinggi kedua di ASEAN setelah Kamboja.

Perkawinan dini adalah segala bentuk pernikahan yang terjadi sebelum anak berusia 18 tahun. Kitab Undang-Undang Hukum Perdata (KUHPerdata) Pasal 29 menyatakan bahwa laki-laki yang belum mencapai umur delapan belas tahun penuh dan perempuan yang belum mencapai umur lima belas tahun penuh, tidak dapat mengadakan perkawinan. Sedangkan menurut B.W., orang dikatakan masih dibawah umur apabila ia belum mencapai usia 21 tahun, kecuali jikalau ia sudah kawin.

Namun, berdasarkan Ketentuan Penutup Undang-Undang Perkawinan Pasal 66 bahwa untuk perkawinan dan segala sesuatu yang berhubungan dengan perkawinan berdasarkan Undang-Undang ini, maka dengan berlakunya Undang-Undang ini, ketentuan-ketentuan yang diatur dalam Kitab Undang- Undang Hukum Perdata dinyatakan tidak berlaku. Salah satunya adalah tidak berlakunya ketentuan batas umur perkawinan karena Undang-Undang Nomor 16 tahun 2019 tentang Perkawinan juga mengatur tentang batas umur perkawinan. Dalam Undang-undang Perkawinan bab II pasal 7 ayat 1 disebutkan bahwa perkawinan hanya diizinkan apabila pria dan wanita sudah mencapai umur 19 (sembilan belas) tahun. Dalam pandangan hukum Indonesia, kisaran usia 20-25 tahun bagi wanita tidak masuk dalam lingkup usia dini untuk menikah.

Dari liputan 6 SCTV 12 Nopember 2015, diketahui berdasarkan survei yang dilakukan oleh Plan Internasional, di Indonesia masih banyak terjadi pernikahan dini pada anak dan remaja. Sebanyak 38\% anak perempuan di bawah usia 18 tahun sudah menikah. Sementara persentase laki-laki yang menikah di bawah umur hanya 3,7 \% (persen). Ternyata, ada beberapa penyebab yang mendorong mereka melakukan pernikahan dini. Hasil penelitian ini membuktikan kuatnya tradisi dan cara pandang masyarakat, terutama di pedesaan, masih menjadi pendorong bagi sebagian anak perempuan lain.

Pernikahan anak merupakan masalah sosial dan ekonomi, yang diperumit dengan tradisi dan budaya dalam kelompok masyarakat. Stigma sosial mengenai pernikahan setelah 
melewati masa pubertas yang dianggap aib pada kalangan tertentu, meningkatkan pula angka kejadian pernikahan anak. Motif ekonomi, harapan tercapainya keamanan sosial dan finansial setelah menikah menyebabkan banyak orangtua menyetujui pernikahan usia dini.

Dalam realitasnya pernikahan dini akan menimbulkan dampak bagi pelakunya baik dampak negatif, dan hal ini akan mempengaruhi kehidupan pribadi maupun sosial yang melakukannya. Sehingga juga hal ini tidak menutup kemungkinan pernikahan dini tidak mendatangkan kebahagiaan keluarga, sebagaimana tujuan dari pernikahan itu sendiri, tetapi justru akan mendatangkan kemadharatan bahka mungkin kesengsaraan bagi yang menjalaninya.

\section{Metode Penelitian}

Penelitian ini termasuk penelitian pustaka (library research) dengan menggunakan Metode kualitatif dengan pendekatan deskriptif, yang bisa dipahami sebagai serangkaian prosedur yang digunakan dalam upaya pemecahan masalah yang diselidiki dengan menggambarkan atau melukiskan obyek penelitian (Yusuf, 2016).

\section{Hasil dan Pembahasan}

\section{Faktor yang mempengaruhi Perkawinan Dini}

(Kependudukan, 2014) menyatakan bahwa, faktor-faktor yang mempengaruhi terjadinya pernikahan dini adalah faktor pendidikan rendah, faktor kebutuhan ekonomi, faktor kultur nikah muda, pernikahan yang diatur serta seks bebas pada remaja.

1. Pendidikan

Pendidikan sangat mempengaruhi pola pemikiran suatu masyarakat untuk mengambil keputusan. Salah satu faktor terjadinya perkawinan dini lainnya adalah pendidikan remaja dan pendidikan orang tua. Dalam kehidupan seseorang, dalam menyikapi masalah dan membuat keputusan termasuk hal yang lebih kompleks ataupun kematangan psikososialnya sangat dipengaruhi oleh tingkat pendidikan seseorang (Soraya, 2018). Tingkat pendidikan maupun pengetahuan anak yang rendah dapat menyebabkan adanya kecenderungan melakukan perkawinan di usia dini (Amelia et al., 2017). Tingkat pendidikan merupakan faktor penting dalam logika berpikir untuk menentukan perilaku menikah di usia muda, perempuan yang berpendidikan rendah pada umumnya menikah dan memiliki anak di usia muda (Notoatmodjo, 2007). Pendidikan orang tua juga memiliki peranan dalam keputusan buat anaknya, karena di dalam lingkungan keluarga, pendidikan anak yang pertama dan utama (Kurniawati \& Sari, 2020).

(Anggraini, 2017) mengemukakan bahwa peran orang tua terhadap kelangsungan perkawinan dini pada dasarnya tidak terlepas dari tingkat pengetahuan orang tua yang dihubungkan pula dengan tingkat pendidikan orang tua. Orang tua juga memiliki peran yang besar untuk penundaan usia perkawinan anak (Arimurti \& Nurmala, 2017). Peran orang tua sangat penting dalam membuat keputusan menikah di usia muda dimana keputusan untuk menikah di usia muda merupakan keputusan yang terkait dengan latar belakang relasi yang terbangun antara orang tua dan anak dengan lingkungan pertemanannya (Desiyanti, 2015).

2. Ekonomi

Masalah ekonomi pada keluarga sering kali menjadi penyebab orang tua untuk menikahkan anaknya dengan orang yang dianggap lebih mampu, karena orang tua sudah tidak 
mampu membiayai kebutuhan hidup dan sekolahnya, sehingga membuat anak untuk mengambil keputusan melakukan pernikahan di usia dini dengan alas an mengurangi beban ekonomu keluarga.

(Jannah, 2012) menjelaskan dalam penelitiannya bahwa para orang tua yang menikahkan anaknya pada usia muda mengganggap bahwa dengan menikahkan anaknya, maka beban ekonomi keluarga akan berkurang satu. Faktor ini berhubungan dengan rendahnya status ekonomi keluarga. Anggapan bahwa jika seorang remaja putri sudah menikah, maka akan tanggung jawabnya akan dialihkan kepada suaminya. Bahkan para orang tua yang menikahkan anaknya di usia dini juga berharap jika anaknya sudah menikah akan dapat membantu meningkatkan kehidupan orang tuanya

\section{Keinginan Sendiri}

Faktor ini sangat sulit dihindari, karena pria dan wanita berpikiran bahwa mereka saling mencintai bahkan tanpa memandang usia mereka, tanpa memandang masalah apa yang akan dihadapi dan apakah mereka mampu untuk memecahkan suatu masalah. Adanya perasaan saling cinta dan sudah merasa cocok. Dalam kondisinya yang sudah memiliki pasangan dan pasangannya berkeinginan yang sama, yaitu menikah di usia muda tanpa memikirkan apa masalah yang dihadapi ke depan jikalau menikah di usia yang masih muda hanya karena berlandaskan sudah saling mencintai, maka la pun melakukan pernikahannya pada usianya yang masih muda.

\section{Lingkungan}

Faktor lain yang juga mempengaruhi kejadian pernikahan dini adalah faktor lingkungan. (Jannah, 2012) menyebutkan bahwa dalam konteks Indonesia pernikahan lebih condong diartikan sebagai kewajiban sosial dari pada manifestasi kehendak bebas setiap individu. (Suhadi, 2012) menjelaskan bahwa dalam masyarakat yang pola hubungannya bersifat tradisional, pernikahan dipersepsikan sebagai suatu "keharusan sosial" yang merupakan bagian dari warisan tradisi dan dianggap sakral. Cara pandang tradisional terhadap perkawinan sebagai kewajiban sosial, tampaknya memiliki kontribusi yang cukup besar terhadap fenomena pernikahan dini yang terjadi di Indonesia. Pernikahan dini di lingkungan remaja cenderung berdampak negatif baik dari segi sosial ekonomi, mental/psikologis, fisik, terutama bagi kesehatan reproduksi sang remaja tersebut (Pohan, 2017).

Dampak dari pernikahan usia dini kesehatan reproduksi salah satunya yaitu perempuan usia 15-19 tahun memiliki kemungkinan dua kali lebih besar meninggal saat melahirkan dibandingkan yang berusia 20-25 tahun, sedangkan usia di bawah 15 tahun kemungkinan meninggal bisa lima kali. Perempuan muda yang sedang hamil, berdasarkan penelitian akan mengalami beberapa hal, seperti akan mengalami pendarahan, keguguran, dan persalinan yang lama atau sulit (Pohan, 2017). Oleh karena itu, pernikahan dini memiliki banyak dampak negatif yang sangat penting untuk diketahui baik oleh remaja maupun orang tua (Desiyanti, 2015). Perkawinan usia anak mengakhiri masa remaja anak perempuan, yang seharusnya menjadi masa bagi perkembangan fisik, emosional dan sosial mereka. Masa remaja ini juga sangat penting bagi mereka karena ini adalah masa dimana mereka dapat mempersiapkan diri 6untuk memasuki masa dewasa. Praktik perkawinan usia anak seringkali menimbulkan dampak buruk terhadap status kesehatan, pendidikan, ekonomi, keamanan anak perempuan 
dan anak-anak mereka, serta menimbulkan dampak yang merugikan bagi masyarakat (Statistik, 2017).

\section{Marriged By Acident}

Penelitian di Indonesia menunjukkan bahwa terkadang pernikahan diusia muda terjadi sebagai solusi untuk kehamilan yang terjadi diluar nikah. Menurut Sarwono (2003) pernikahan diusia muda banyak terjadi pada masa pubertas, hal ini terjadi karena remaja sangat rentan terhadap prilaku seksual yang membuat mereka melakukan aktiivitas seksual sebelum menikah. Hal ini juga terjadi karena adanya kebebasan pergaulan antar jenis kelamin pada remaja, dengan mudah bisa disaksikan dalam kehidupan sehari-hari. Akibat terlalu bebasnya para remaja dalam berpacaran sampai kebabalasan, sehingga para remaja sering melakukan sex pranikah dan akibat dari sex pranikah tersebut adalah kehamilan, yang kemudian solusi yang diambil pihak keluarga adalah dengan menikahkan mereka.

Menurut (Rohmahwati et al., 2008), paparan media massa, baik cetak (koran, majalah, buku-buku porno) maupun elektronik (TV, VCD, Internet), mempunyai pengaruh terhadap remaja untuk melakukan hubungan seksual pranikah. Paparan informasi seksualitas dari media massa (baik cetak maupun elektronik) yang cenderung bersifat pornografi dan pornoaksi dapat menjadi referensi yang tidak mendidik bagi remaja. Remaja yang sedang dalam periode ingin tahu dan ingin mencoba, akan meniru apa yang dilihat atau didengarnya dari media massa tersebut.

\section{Dampak dari perkawinan dini}

Setiap kejadian pasti memiliki dampak terhadap sesuatu, baik positif maupun negatif, begitu juga dengan terjadinya pernikahan dini, akan memiliki dampak secara langsung terhadap siapapun yang menjalaninya. Berdasarkan data penelitian Pusat Kajian Gender dan Seksualitas Universitas Indonesia tahun 2015, terungkap angka perkawinan dini di Indonesia peringkat kedua teratas di kawasan Asia Tenggara. Sekitar 2 juta dari 7,3 perempuan Indonesia berusia di bawah 15 tahun sudah menikah dan putus sekolah. Jumlah itu diperkirakan naik menjadi 3 juta orang pada 2030.

Komisioner Komisi Nasional Anti Kekerasan terhadap Perempuan, Budi Wahyuni, menjabarkan, dari kasus-kasus yang ia tangani, umumnya orangtua menganggap anak bisa melanjutkan pendidikan setelah menikah dengan mengikuti Kejar Paket A, B, dan C. "Kenyataannya, anak yang menikah sudah terlalu lelah karena dipaksa mengurus keluarga," ujar Budi. Serta dampak perkawinan dini bagi anak-anak perempuan yang melangsungkan perkawinan dibawah 18 tahun akan mengalami gangguan- gangguan pada kandungannya yang dapat membahayakan kesehatan anak.

Dampak perkawinan dini juga terjadi pada suami-isteri adalah tidak bisa memenuhi atau tidak mengetahui hak dan kewajiban, hal ini terjadi karena mental mereka yang masih memiliki sifat keegoisan yang tinggi sehingga menyebabkan pertengkaran, percecokkan, bentrokan antar suami isteri yang dapat mengakibatkan perceraian.

Serta dampak bagi masing-masing keluarga, yaitu apabila pernikahan diantara mereka lancar merek akaan ikut senang dan bahagia. Namun apabila pernikahan gagal, maka mereka akan merasa sedih dan kecewa sehinggal dari kegagalan tersebut mengakibatkan putusnya hubungan silahturahmi antar keluarga. 
Perkawinan usia anak memiliki dampak antargenerasi. Bayi yang dilahirkan oleh anak perempuan yang menikah pada usia anak memiliki risiko kematian lebih tinggi, dan kemungkinannya dua kali lebih besar untuk meninggal sebelum usia 1 tahun dibandingkan dengan anak-anak yang dilahirkan oleh seorang ibu yang telah berusia dua puluh tahunan. Bayi yang dilahirkan oleh pengantin anak juga memiliki kemungkinan yang lebih tinggi untuk lahir prematur, dengan berat badan lahir rendah, dan kekurangan gizi. Hal ini berhubungan langsung perempuan menikah yang pada saat kehamilan dan persalinan masih berusia sangat muda, ketika mereka sendiri memiliki tingkat kekurangan gizi yang lebih tinggi dan tubuh mereka belum tumbuh sempurna. Ketika anak perempuan masih dalam proses pertumbuhan, kebutuhan gizi pada tubuhnya akan bersaing dengan kebutuhan gizi pada janinnya (Statistik, 2017).

Serta Kesehatan Reproduksi: kehamilan pada usia kurang dari 17 tahun meningkatkan risiko komplikasi medis, baik pada ibu maupun pada anak. Kehamilan di usia yang sangat muda ini ternyata berkorelasi dengan angka kematian dan kesakitan ibu. Disebutkan bahwa anak perempuan berusia 10-14 tahun berisiko lima kali lipat meninggal saat hamil maupun bersalin dibandingkan kelompok usia 20-24 tahun, sementara risiko ini meningkat dua kali lipat pada kelompok usia 15-19 tahun. Hal ini disebabkan organ reproduksi anak belum berkembang dengan baik dan panggul juga belum siap untuk melahirkan. Data dari UNPFA tahun 2003, memperlihatkan 15\%-30\% di antara persalinan di usia dini disertai dengan komplikasi kronik, yaitu obstetric fistula. Fistula merupakan kerusakan pada organ kewanitaan yang menyebabkan kebocoran urin atau feses ke dalam vagina. Selain itu, juga meningkatkan risiko penyakit menular seksual dan penularan infeksi HIV.

Perkawinan usia anak tidak hanya mendasari, tetapi juga mendorong ketidaksetaraan gender dalam masyarakat. Perkawinan usia anak dapat menyebabkan siklus kemiskinan yang berkelanjutan, peningkatan buta huruf, kesehatan yang buruk kepada generasi yang akan datang, dan merampas produktivitas masyarakat yang lebih luas baik dalam jangka pendek maupun jangka panjang.

\section{Kesimpulan}

Pernikahan anak merupakan masalah sosial dan ekonomi, yang diperumit dengan tradisi dan budaya dalam kelompok masyarakat. Stigma sosial mengenai pernikahan setelah melewati masa pubertas yang dianggap aib pada kalangan tertentu, meningkatkan pula angka kejadian pernikahan anak. Motif ekonomi, harapan tercapainya keamanan sosial dan finansial setelah menikah menyebabkan banyak orangtua menyetujui pernikahan usia dini.

Dalam realitasnya pernikahan dini akan menimbulkan dampak bagi pelakunya baik dampak negatif, dan hal ini akan mempengaruhi kehidupan pribadi maupun sosial yang melakukannya. Sehingga juga hal ini tidak menutup kemungkinan pernikahan dini tidak mendatangkan kebahagiaan keluarga, sebagaimana tujuan dari pernikahan itu sendiri, tetapi justru akan mendatangkan kemadharatan bahka mungkin kesengsaraan bagi yang menjalaninya. 


\section{Bibliografi}

Amelia, R., Mohdari, M., \& Azizah, A. (2017). Pengaruh penyuluhan terhadap pengetahuan remaja tentang pernikahan dini di kelas VIII di SMP Negeri 4 Banjarmasin. Dinamika Kesehatan: Jurnal Kebidanan Dan Keperawatan, 8(1), 64-77.

Anggraini, F. (2017). Persepsi Orang Tua Terhadap Pernikahan Dini Di Desa Gedang Kulut Kecamatan Cerme Kabupaten Gresik Ditinjau Dari Tingkat Pendidikan. Kajian Moral Dan Kewarganegaraan, 5(02).

Arimurti, I., \& Nurmala, I. (2017). Analisis Pengetahuan Perempuan Terhadap Perilaku Melakukan Pernikahan Usia Dini Di Kecamatan Wonosari Kabupaten Bondowoso. The Indonesian Journal of Public Health, 12(2), 249-262.

Desiyanti, I. W. (2015). Faktor-faktor yang berhubungan terhadap pernikahan dini pada pasangan usia subur di Kecamatan Mapanget Kota Manado. Jikmu, 5(3).

Jannah, U. S. F. (2012). Pernikahan dini dan implikasinya terhadap kehidupan keluarga pada masyarakat Madura (perspektif hukum dan gender). EGALITA.

Kependudukan, B. (2014). Badan Kependudukan dan Keluarga Berencana Nasional. Diunduh.

Kurniawati, N., \& Sari, K. I. P. (2020). Determinan Faktor Pemicu Terjadinya Pernikahan Dini Pada Usia Remaja. Jurnal Keperawatan, 13(1), 12.

Notoatmodjo. (2007). Tindakan seseorang dipengaruhi oleh Sikapnya. PT Rineka Cipta.

Pohan, N. H. (2017). Faktor-Faktor yang Berhubungan Dengan Pernikahan Usia Dini terhadap Remaja Putri. Jurnal Endurance, 2(3), 424-435.

Rohmahwati, D. A., Lutfiati, A., \& Sri, M. (2008). Pengaruh Pergaulan Bebas Dan Ved Porno Terhadap Perilaku Remaja Di Masyarakat. Jurnal Promosi Kesehatan Indonesia, 2(2), 34-56.

Soraya, D. (2018). Dampak pernikahan usia dini: analisis feminis pada pernikahan anak perempuan di Desa Cibunar Kecamatan Cibatu Kabupaten Garut. UIN Sunan Gunung Djati Bandung.

Statistik, B. P. (2017). Badan pusat statistik. Badan Pusat Statistik.

Suhadi, S. (2012). Pernikahan Dini, Perceraian, dan Pernikahan Ulang: sebuah Telaah dalam Perspektif Sosiologi. Komunitas: International Journal of Indonesian Society and Culture, 4(2), 168776.

Yusuf, A. M. (2016). Metode penelitian kuantitatif, kualitatif \& penelitian gabungan. 
Permasalahan Perkawinan Dini di Indonesia

Prenada Media. 